\title{
PENERAPAN NILAI-NILAI KARAKTER MELALUI PROGRAM INTRAKURIKULER DAN EKSTRAKURIKULER
}

\section{APLICATION OF CHARACTER VALUES THROUGH INTRACURRICULAR AND EXTRACURRICULAR PROGRAMS}

\author{
Nurliyah $^{1 a}$, H Bisri ${ }^{1}$, dan Y Hartati ${ }^{1}$ \\ 1 Program Studi Pendidikan Guru Sekolah Dasar, Fakultas Keguruan dan Ilmu Pendidikan, \\ Universitas Djuanda Bogor, Jl. Tol Ciawi No. 1 Kotak Pos 35 Ciawi Bogor 16720 \\ a Korespondensi: Nurliyah, Email: nurliyah@unida.ac.id
}

(Diterima: 22-01-2017; Ditelaah: 23-01-2017; Disetujui: 05-04-2017)

\begin{abstract}
Character education is a proactive effort by formal, informal, and non-formal institutions. It is one of the solutions to overcome moral decline especially among teenagers (students). It is closely related to education in schools as a formal institution. Schools play an important role as a vehicle to strengthen the nation's character. This study aims to find and describe character education SDIT Al-Utsmaniyah. The method of this study is qualitative ethnography. The results showed that character education programs are designed through school intra-curricular and extracurricular programs. Curriculum used is the curriculum Kemendiknas combined with the curriculum Kemenag and special curriculum SDIT AlUtsmaniyah. School stakeholders play an important role in fostering the character values of SDIT Al-Utsmaniyah students. It can be seen that in applying the character education program, schools involved not only teachers but also all foundations, committees, education personnel, parents and the surrounding community.
\end{abstract}

Keywords: character education, ethnography education.

\begin{abstract}
ABSTRAK
Pendidikan karakter merupakan upaya proaktif yang dilakukan oleh lembaga formal, informal, maupun nonformal. Pendidikan karakter merupakan salah satu solusi untuk mengatasi kemerosotan moral khususnya kemerosotan moral di kalangan remaja (peserta didik). Pendidikan karakter berkaitan erat dengan pendidikan di sekolah sebagai lembaga formal. Sekolah berperan penting sebagai wahana memperteguh karakter bangsa. Penelitian ini bertujuan untuk mendeskripsikan penerapan pendidikan karakter SDIT Al-Utsmaniyah. Metode penelitian ini adalah kualitatif etnografi. Hasil penelitian menunjukkan bahwa program pendidikan karakter dirancang melalui program intrakurikuler dan ekstrakurikuler sekolah. Kurikulum yang digunakan yaitu kurikulum dari Kemendiknas yang dipadukan dengan kurikulum Kemenag dan kurikulum khusus SDIT Al-Utsmaniyah. Stakeholder sekolah berperan penting dalam menumbuhkan nilai-nilai karakter pada peserta didik SDIT Al-Utsmaniyah. Hal ini dapat dilihat bahwa dalam menerapkan program pendidikan karakter sekolah tidak hanya melibatkan guru tetapi melibatkan seluruh yayasan, komite, tenaga kependidikan, orang tua serta masyarakat sekitar.
\end{abstract}

Kata kunci: etnografi pendidikan, pendidikan karakter.

Nurliyah, H Bisri, dan Y Hartati. 2017. Penerapan nilai-nilai karakter melalui program intrakurikuler dan ekstrakurikuler. Didaktika Tauhidi Jurnal Pendidikan Guru Sekolah Dasar 4(1): 59-74. 


\section{PENDAHULUAN}

Indonesia merupakan negara yang terkenal dengan budaya ketimuran. Budaya timur menjadi karakter bangsa Indonesia yang dipuji negara lain. Bangsa Indonesia terkenal dengan karakter yang religius, jujur, toleransi, demokratis, dan cinta damai. Tujuh puluh dua tahun Indonesia merdeka sudah banyak perkembangan yang dirasakan. Walaupun demikian, dewasa ini bangsa Indonesia mengalami degradasi sebagai bangsa yang berkarakter.

Degradasi karakter bangsa terlihat dari banyaknya kejahatan yang terjadi di Indonesia. Menurut laporan Numbeo dalam jurnal Indonesia Corruption Watch (2015), indeks kejahatan di Indonesia adalah 46,10 kasus kejahatan yang terjadi di antaranya kriminalitas, kekerasan dan korupsi. Data terakhir dari Komisi Nasional Perlindungan Anak periode Maret 2015, kasus kekerasan seksual memiliki persentase tertinggi yaitu sebesar 35\%. Meningkatnya kejahatan di masyarakat bahkan berujung pembunuhan serta berkembangnya kasus bullying di sekolah yang mengatas namakan suku bahkan agama, sudah menjadi sajian yang selalu hangat di surat kabar maupun televisi. Ketua KPAI Asrorun Ni'am Sholeh mengatakan angka kekerasan anak sebagai pelaku bullying (kekerasan di sekolah) mengalami peningkatan dari 67 kasus (2014) menjadi 79 kasus (2015). Sementara itu, angka anak sebagai pelaku aksi tawuran meningkat dari 46 kasus (2014) menjadi 103 kasus (2015).

Uraian di atas merupakan beberapa fakta yang menunjukkan bahwa karakter bangsa ini mulai lemah dan hilang. Di tengah permasalahan tersebut banyak kalangan mencari solusi terbaik untuk menumbuhkan kembali karakter ketimuran, salah satu cara efektif untuk menumbuhkan kembali karakter bangsa yaitu melalui pendidikan karakter.

Salah satu upaya untuk menumbuhkan nilai-nilai karakter yaitu melalui pendidikan karakter di sekolah. Pada umumnya Sekolah Dasar Islam Terpadu (SDIT) menggunakan sistem full day school. Bentuk full day school yang diterapkan yaitu mengimplementasikan pendidikan karakter dengan memadukan kurikulum kemendiknas dengan kurikulum kemenag dan kurikulum khusus yang dibuat sekolah. Penerapan full day school merupakan alternatif dari revolusi pendidikan terhadap masalah- masalah yang ada dan terjadi pada siswa. Sebagai solusi alternatif pelaksanaan full day school ditunjang dengan berbagai alasan yang patut dipertimbangkan dalam pendidikan siswa. Meskipun SDIT AlUtsmaniyah terletak di sebuah desa yang jauh dari pusat kota Bogor akan tetapi SDIT Al- Utsmaniyah memiliki best practice dalam program pendidikan karakter.

Penelitian ini didukung oleh pendapat para ahli. Samami dan Hariyanto (2011) mendefinisikan pendidikan karakter adalah proses pemberian tuntunan kepada peserta didik untuk menjadi manusia seutuhnya yang berkarakter dalam dimensi hati, pikir, raga, serta rasa dan karsa. Pendidikan karakter menurut Mulyasa (2013) tidak hanya berkaitan dengan masalah benarsalah, tetapi bagaimana menanamkan kebiasaan (habit) tentang hal-hal baik dalam kehidupan, sehingga siswa memiliki kesadaran, dan pemahaman yang tinggi, serta kepedulian dan komitmen untuk menerapkan kebajikan dalam kehidupan sehari-hari.

Dari uraian di atas perlu diadakan penelitan etnografi guna menumbuhkan nilai-nilai karakter pada peserta didik 
khususnya di sekolah dasar, antara lain untuk mendeskripsikan program pendidikan karakter di Sekolah Dasar Islam Terpadu (SDIT) serta memperoleh dan mensosialisasikan praktik terbaik pendidikan karakter di Sekolah Dasar Islam Terpadu (SDIT).

\section{MATERI DAN METODE}

\section{Materi}

Pendidikan karakter tidak hanya berkaitan dengan masalah benar-salah, tetapi bagaimana menanamkan kebiasaan (habit) tentang hal-hal baik dalam kehidupan, sehingga siswa memiliki kesadaran, dan pemahaman yang tinggi, serta kepedulian dan komitmen untuk menerapkan kebajikan dalam kehidupan sehari-hari.

Pendidikan karakter mempunyai kedudukan penting dalam Islam, Sebagaimana firman Allah SWT di dalam AlQur'an surat An-Nahl ayat 90:

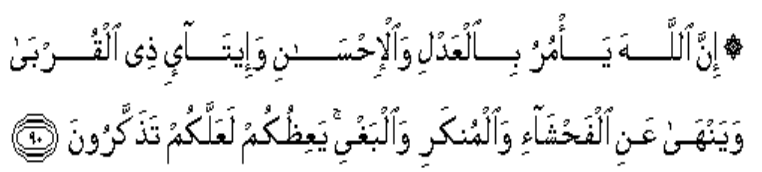

"Sesungguhnya Allah menyuruh (kamu) berlaku adil dan berbuat kebajikan, memberi kepada kaum kerabat, dan Allah melarang dari perbuatan keji, kemungkaran dan permusuhan. Dia memberi pengajaran kepadamu agar kamu dapat mengambil pelajaran."

Ayat di atas menjelaskan bahwa manusia diperintahkan Sang Khalik untuk menjauhkan diri dari permusuhan, sebab tindakan tersebut dapat menjadikan manusia menjadi insan yang berkarakter, baik dalam hal pikiran, hati, rasa serta karsa.

Tujuan pendidikan karakter adalah untuk meningkatkan mutu penyelenggaraan dan hasil pendidikan yang mengarah pada pencapaian pembentukan karakter dan akhlak mulia peserta didik secara utuh, terpadu, dan seimbang. Melalui pendidikan karakter diharapkan peserta didik mampu secara mandiri meningkatkan dan menggunakan pengetahuannya, mengkaji dan menginternalisasi, serta mempersonalisasi nilai-nilai karakter dan akhlak mulia sehingga terwujud dalam perilaku sehari-hari. Pada tingkat institusi, pendidikan karakter mengarah pada pembentukan budaya sekolah, yaitu nilainilai yang melandasi perilaku, tradisi, kebiasaan keseharian, dan simbol-simbol yang dipraktikkan oleh semua warga sekolah, dan masyarakat sekitar sekolah. Budaya sekolah merupakan ciri khas, karakter, atau watak, dan citra sekolah tersebut di mata masyarakat luas.

Sasaran pendidikan karakter adalah seluruh warga civitas akademika yang terdapat pada setiap satuan pendidikan, baik negeri maupun swasta. Semua warga sekolah, yang meliputi para peserta didik, guru, karyawan administrasi, dan pimpinan sekolah, menjadi sasaran program ini. Sekolah-sekolah yang selama ini telah berhasil melaksanakan pendidikan karakter dengan baik dapat dijadikan sebagai best practice, yang menjadi contoh untuk disebarluaskan ke sekolah-sekolah lain. Melalui program ini diharapkan lulusannya memiliki keimanan dan ketakwaan kepada Tuhan Yang Maha Esa, berakhlak mulia, berkarakter mulia, kompetensi akademik yang utuh dan terpadu, sekaligus memiliki kepribadian yang baik sesuai norma-norma dan budaya Indonesia. Pada tataran yang lebih luas, pendidikan karakter nantinya diharapkan menjadi budaya sekolah.

Dasyim Budimasyah berpendapat bahwa program pendidikan karakter di sekolah perlu dikembangkan dengan berdasarkan pada prinsip-prinsip sebagai berikut: 1) 
Pendidikan karakter di sekolah harus dilaksanakan secara berkelanjutan (kontinuitas). Hal ini mengandung arti bahwa proses pengembangan nilai-nilai karakter merupakan proses yang panjang, mulai sejak awal peserta didik masuk sekolah hingga mereka lulus sekolah pada suatu satuan pendidikan, 2) Pendidikan karakter hendaknya dikembangkan melalui semua mata pelajaran (terintegrasi), melalui pengembangan diri, dan budaya suatu satuan pendidikan. Pembinaan karakter bangsa dilakukan dengan mengintegrasikan dalam seluruh mata pelajaran, dalam kurikuler mata pelajaran, sehingga semua mata pelajaran diarahkan pada pengembangan nilai-nilai karakter tersebut. Pengembangan nilai-nilai karakter juga dapat dilakukan melalui pengembangan diri, baik melalui konseling maupun kegiatan ekstrakurikuler, seperti kegiatan kepramukaan, dan lain sebagainya, 3) sejatinya nilai-nilai karakter tidak diajarkan (dalam bentuk pengetahuan), jika hal tersebut diintegrasikan dalam mata pelajaran. Kecuali bila dalam bentuk mata pelajaran agama (yang di dalamnya mengandung ajaran) maka tetap diajarkan dengan proses, pengetahuan (knowing), melakukan (doing), dan akhirnya membiasakan (habit). 4) proses pendidikan dilakukan peserta didik secara aktif (active learning) dan menyenangkan (enjoy full learning). Proses ini menunjukkan bahwa proses pendidikan karakter dilakukan oleh peserta didik bukan oleh guru. Sedangkan guru menerapkan prinsip "tut wuri handayani” dalam setiap perilaku yang ditunjukkan oleh agama.

Pendidikan karakter merupakan wujud kebudayaan sistem yakni tingkah laku dan tindakan yang berpola. Sebagai wujud kebudayaan pendidikan karakter bersifat kontinu sepanjang perjalanan hidup manusia, selain itu pendidikan karakter merupakan upaya untuk menjadikan manusia seutuhnya dalam berbagai dimensi baik hati, raga, rasa serta karsa.

Hal tersebut berarti pendidikan karakter merupakan salah satu unsur kebudayaan yang penting. Pembentukan karakter dapat dimulai dari pembiasaan di lembaga formal, informal maupun non-formal. Kebudayaan akan lebih baik jika ditopang oleh pembiasaan, sebab segala sesuatu yang sudah menjadi kebiasaan atau telah berpola akan melekat dalam diri setiap individu. Dalam konteks inilah terlihat bahwa kebudayaan tidak dapat terlepas dari unsur pendidikan.

Pendidikan karakter dapat diimplementasikan melalui budaya sekolah. Budaya sekolah adalah sekumpulan norma, nilai, dan tradisi yang telah dibangun dalam waktu lama oleh semua warga sekolah dan mengarah ke seluruh aktivitas personel sekolah. Budaya yang baik akan secara efektif menghasilkan kinerja yang baik pada setiap individu, kelompok kerja, sekolah sebagai satu institusi, dan hubungan sinergis antara ketiga tingkatan kinerja tersebut. Budaya sekolah bersifat mengikat dan akan menjadi tingkah laku yang berpola jika dilaksanakan secara kontinu. Dari sifat tersebut maka nilai-nilai karakter akan mulai terbentuk dan secara lambat-laun akan mendarah daging dalam setiap aktivitas seseorang. Dengan demikian dapat dikatakan bahwa pendidikan karakter telah menjadi sebuah pembiasaan.

\section{Metode}

\section{Lokasi Penelitian}

Penelitian ini dilakukan di Sekolah Dasar Islam Terpadu (SDIT) Al-Utsmaniyah Kabupaten Bogor. 


\section{Metode Penelitian}

Jenis penelitian ini ialah penelitian kualitatif etnografi. Penelitian ini menggunakan metode kualitatif, yaitu penelitian yang berpegang kepada paradigma naturalistic atau fenomenologi. Penelitian kualitatif senantiasa dilakukan dalam setting alamiah terhadap suatu fenomena (Iskandar 2013). Data yang diperoleh akan disajikan dalam bentuk deskripsi untuk mengetahui program pendidikan karakter di SDIT AlUtsmaniyah.

\section{Sumber Data}

Pada penelitian ini sumber data mencakup key person dan partisipan. Adapun yang dimaksud sebagai key person dalam penelitian ini adalah kepala sekolah di SDIT Al- Utsmaniyah. Partisipan penelitian adalah orang-orang yang menjadi sumber data tambahan yang terlibat dalam penelitian. Partisipan penelitian yaitu wakil kepala sekolah bagian kurikulum, wakil kepala sekolah bagian kesiswaan, guru-guru, peserta didik, dan orang tua.

\section{Teknik Pengumpulan Data}

Teknik Pengumpulan data dilakukan untuk memperoleh data yang diperlukan dalam penelitian. Dalam penelitian ini digunakan beberapa metode sebagai berikut.

1. Wawancara mendalam. Wawancara mendalam dilakukan karena peneliti ingin mengetahui hal-hal yang lebih mendalam dari responden. Wawancara mendalam dilakukan kepada kepala sekolah, guru, dan peserta didik.

2. Observasi. Teknik ini digunakan peneliti untuk mengamati, memahami peristiwa secara cermat, mendalam dan terfokus terhadap subjek penelitian, baik dalam suasana formal maupun santai.
3. Kuesioner. Kuesioner bertujuan untuk memperoleh data atau informasi mengenai masalah penelitian yang menggambarkan variabel-variabel yang diteliti.

4. Studi dokumentasi. Teknik ini merupakan penelaahan terhadap referensi-referensi yang berhubungan dengan fokus permasalahan penelitian.

\section{Teknik Analisis Data}

Teknik analisis data pada penelitian ini menggunakan analisis data Spradley dimana langkah-langkahnya adalah sebagai berikut.

1. Analisis Domain

Analisis domain dilakukan untuk memperoleh gambaran yang umum dan menyeluruh dari objek penelitian atau setting sosial. Domain-domain fenomena yang terjadi di lapangan dilakukan dengan melakukan grand tour dan mini tour. Dalam analisis domain peneliti menetapkan domain-domain yang akan diteliti melalui fenomena-fenomena lapangan yang berhubungan dengan aktivitas, tempat, subjek (place, actor, activity), dan aktivitas di lapangan. Pengumpulan data lapangan sangat diperlukan sebagai dasar menjalankan penelitian, semakin banyak yang dipilih, maka semakin banyak waktu diperlukan untuk pengumpulan data dan analisis data, sehingga diharapkan mendapat temuan yang baik.

\section{Analisis Taksonomi}

Analisis taksonomi merupakan langkah lanjut dari analisis domain, hasil analisis domain tersebut dijabarkan lebih rinci dan lebih terfokus, sehingga nampak secara detail apa-apa yang berhubungan dengan domain-domain tersebut. Analisis taksonomi ini dilakuakn dengan menggunakan teknik observasi terfokus, 
wawancara mendalam, dan studi dokumen yang berhubungan dengan domain-domain yang diteliti.

3. Analisis Komponensial

Analisis komponensial merupakan kelanjutan dari analisis taksonomi, dimana domain yang telah dijadikan fokus melalui analisis taksonomi. Analisis komponenesial untuk mencari perbedaan atau yang kontras dari data studi dokumen.

4. Analisis Tema Budaya

Analisis tema budaya merupakan kelanjutan dari analisis domain, analisis taksonomi, dan analisis komponensial. Dari ketiga analisis ini, maka akan mendapatkan konstruksi bangunan yang utuh yang menjelaskan tentang (place, actor, activity) setting sosial yang selama ini kabur, dengan adanya analisis ini maka akan menjadi terang (Iskandar 2013).

\section{HASIL DAN PEMBAHASAN}

\section{Hasil}

\section{Gambaran Umum SDIT Al-Utsmaniyah}

SDIT Al-Utsmaniyah merupakan salah satu sekolah yang mengedepankan pendidikan karakter. Sekolah ini berdiri sejak tahun 2006 terletak di Jalan Sabilillah Kampung Dukuh Desa Pasir Mukti Citeureup-Bogor. SDIT Al-Utsmaniyah berada di sebelah kiri jalan dari arah tol Jagorawi dan berada diantara pemukiman warga. Sekolah ini berdiri di atas tanah wakaf seluas $5000 \mathrm{~m}^{2}$ dengan luas bangunan sebesar $2500 \mathrm{~m}^{2}$ serta memiliki status akreditasi A.

SDIT Al-Utsmaniyah sebagai suatu lembaga pendidikan telah merancang sebuah program pendidikan karakter yang bertujuan untuk menumbuhkan nilai-nilai karakter pada peserta didik. Program yang diterapkan diharapkan mampu mengintegrasikan kurikulum kemendiknas dengan kurikulum kemenag dan kurikulum khusus yang dibuat oleh SDIT AlUtsmaniyah, serta dapat mewujudkan visi SDIT Al-Utsmaniyah yaitu "pelopor pendidikan terpadu menuju terbentuknya generasi atau lulusan shalih dan berprestasi".

Adapun hasil dari penelitian ini terdiri dari tiga data yaitu program pendidikan karakter, penerapan pendidikan karakter, dan peran guru dan orang tua dalam menumbuhkan karakter peserta didik.

\section{Program Pendidikan Karakter}

Program merupakan susunan dari beberapa kegiatan yang dibuat untuk mencapai tujuan tertentu. Sekolah sebagai lembaga pendidikan pasti memiliki tujuan. Tujuan tersebut dapat tercapai jika didukung dengan program-program yang bermutu. SDIT Al-Utsmaniyah sebagai suatu lembaga pendidikan telah merancang sebuah program pendidikan karakter yang bertujuan untuk menumbuhkan nilai-nilai karakter pada peserta didik. Tujuan dari program yang dibuat SDIT Al-Utsmaniyah tersebut sejalan dengan tujuan pendidikan nasional yang tercantum dalam Permendikbud Nomor 23 tahun 2015. Untuk mempermudah proses penumbuhan nilai-nilai karakter pada peserta didik SDIT Al-Utsmaniyah dapat dilihat pada alur Gambar 1.

Pada alur Gambar 1 menunjukkan bahwa untuk menumbuhkan nilai-nilai karakter pada peserta didik maka SDIT AlUtsmaniyah menerapkan sistem full day school, dimana peserta didik memiliki jam belajar mulai dari pukul 07.30-15.00. Jam belajar tersebut dianggap efektif untuk menerapkan program pendidikan karakter 
yang sudah dirancang. Program dirancang melalui pengintegrasian dengan kegiatan belajar mengajar, kegiatan ekstrakurikuler, dan melalui budaya sekolah. Ketiga rancangan program tersebut diharapkan dapat menumbuhkan nilai-nilai karakter dalam diri peserta didik dan akan menjadi sebuah ciri khas dari setiap individu.

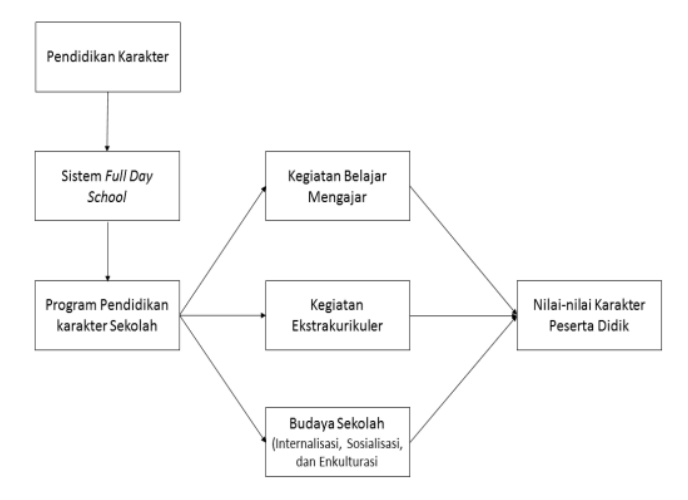

Gambar 1 Alur proses penumbuhan nilainilai karakter pada peserta didik

Berdasarkan perencanaan yang telah dibuat, SDIT Al-Utsmaniyah menerapkan program-program pendidikan karakter dengan mengintegrasikannya melalui program intrakurikuler maupun ektrakurikuler sekolah. Adapun program intrakurikuler sekolah terkait pendidikan karakter di SDIT Al-Utsmaniyah di antaranya sebagai berikut.

\section{a. Outdoor Learning}

Outdoor Learning merupakan program belajar di luar kelas, maksudnya yaitu sekolah memberikan wewenang kepada wali kelas maupun guru mata pelajaran untuk membuat proses pembelajaran lebih bervariasi. Sasaran dari program outdoor learning yaitu seluruh peserta didik SDIT AlUtsmaniyah dan guru SDIT Al-Utsmaniyah, karena selain peserta didik yang belajar tetapi guru pun dapat belajar dari teman sejawat untuk bertukar pikiran mengembangkan kegiatan belajar di luar kelas. Tujuan dari program ini adalah untuk menanamkan nilai-nilai karakter pada peserta didik dan mengembangkan proses pembelajaran di SDIT Al-Utsmaniyah.

b. Pembiasaan Islami

Pembiasaan islami merupakan salah satu program dari kurikulum khusus. Peserta didik SDIT Al-Utsmaniyah dalam keseharian di sekolah dibiasakan untuk menerapkan pembiasaan islami seperti makan dan minum sambil duduk, melaksanakan salat sunah dhuha, berbagi kebaikan dengan sesama, membiasakan salat wajib berjamaah serta membiasakan membaca AlQur'an.

Sekolah menerapkan program ini dengan tujuan agar peserta didik paham akan kewajibannya sebagai umat muslim serta menumbuhkan nilai-nilai karakter seperti religius, jujur, toleransi, disiplin, mandiri, peduli dan tanggung jawab. Selain peserta didik guru SDIT Al-Utsmaniyah pun menjadi sasaran dalam program pembiasaan islami karena guru merupakan teladan bagi peserta didik, sehingga sebelum peserta didik melakukan maka guru terlebih dahulu yang harus melakukan.

\section{c. Outing Class}

Sumber belajar bukan hanya guru dan buku akan tetapi sebuah tempat juga dapat dijadikan sumber belajar untuk peserta didik. SDIT Al-Utsmaniyah mengadakan outing class satu tahun sebanyak 1 kali, biasanya sekolah mengunjungi tempat yang dapat memberikan wawasan kepada peserta didik. Program ini bertujuan mengenalkan dunia luar pada peserta didik sehingga peserta didik dapat mengembangkan cara berpikir nya menjadi lebih kritis dan ilmiah. Secara tidak langsung sekolah pun sedang membentuk karakter peserta didik agar menjadi pribadi yang kreatif, memiliki rasa ingin tau yang tinggi serta mampu bertanggung jawab. 


\section{d. Arabic and English Time}

Program ini merupakan program terbaru di SDIT Al-Utsmaniyah yang bertujuan agar peserta didik memiliki kemampuan berkomunikasi dengan multi bahasa, dapat bersaing di ranah nasional maupun internasional. Setiap hari Rabu di minggu pertama dan ketiga pada jam istirahat peserta didik dan guru diharuskan berkomunikasi menggunakan bahasa Inggris, sedangkan minggu kedua dan keempat peserta didik dan guru diharuskan berkomunikasi dengan bahasa Arab.

\section{e. Supercamp}

Supercamp merupakan program SDIT AlUtsmaniyah yang mengajak peserta didik untuk berkemah di luar sekolah. Program ini dilakukan satu tahun sekali dan biasanya sekolah melibatkan pembina pramuka dan guru-guru untuk merancang kegiataan pada saat supercamp. Peserta didik tidak hanya berkemah, akan tetapi pembina merancang pula kegiatan yang bertujuan untuk menumbuhkan nilai-nilai karakter pada peserta didik. Nilai-nilai karakter tersebut diantaranya nilai religius yang diaplikasikan ke dalam kegiatan salat berjamaah, nilai peduli sosial seperti kegiatan mengumpulkan dana peduli bencana dari masyarakat sekitar, dan nilai karakter peduli lingkungan yang diaplikasikan dalam bentuk kegiatan penghijauan.

\section{f. Pentas Seni}

SDIT Al-Utsmaniyah mengadakan pentas seni satu tahun sekali saat kenaikan kelas. Program ini bertujuan agar peserta didik mampu menampilkan bakat yang dimilki serta melatih peserta didik untuk berkreasi dalam bidang seni. Saat pentas seni diadakan setiap kelas wajib menampilkan bakat yang dimilki oleh peserta didik. Guru bertugas melatih dan mengelompokkan peserta didik sesuai dengan bakat yang dimilki, selain itu sekolah mengundang orang tua untuk dapat hadir menyaksikan pentas seni

\section{g. Keputrian}

Keputrian merupakan program SDIT AlUtsmaniyah yang dikhususkan untuk peserta didik perempuan. Peserta didik perempuan berkumpul satu minggu sekali yakni pada hari Jum'at saat peserta didik laki-laki melaksanakan salat Jum'at. Keputrian biasanya diisi dengan berbagai kegiatan diantaranya kajian mengenai perempuan, bercerita kisah-kisah nabi, shalawatan, mengaji, permainan, dan acara ngarujak bersama.

Pembina atau mentor adalah guru SDIT Al-Utsmaniyah. SDIT Al-Utsmaniyah membuat program keputrian dengan tujuan mengenalkan hal-hal yang berkenaan dengan perempuan dan agama Islam sejak usia dini agar kelak saat dewasa peserta didik sudah paham dan mengaplikasikan dengan baik.

Program pendidikan karakter lain di SDIT Al-Utsmaniyah dirancang dalam bentuk kegiatan ekstrakurikuler. Pembina dalam setiap ekstrakurikuler diberikan tanggung jawab untuk merancang program sendiri dan dipresentasikan saat rapat kerja tahunan di awal tahun pelajaran baru. Tujuan dari kegiatan esktrakurikuler yaitu sebagai wadah berkembangnya minat bakat peserta didik serta menumbuhkan nilai-nilai karakter dalam bentuk kegiatan yang menyenangkan.

Ada tujuh ekstrakurikuler di antaranya pramuka, futsal, pencak silat, marawis, kaligrafi, dokter kecil, dan sains club. Berikut penjelasan dari setiap ekstrakurikuler.

a. Pramuka

Pramuka merupakan ektrakurikuler wajib untuk peserta didik SDIT ALUtsmaniyah. Kegiatan ekstrakurikuler 
pramuka diadakan setiap hari Jum'at setelah salat Jum'at dan sebelum peserta didik mengikuti esktrakurikuler pilihan.

Pramuka merupakan wadah gerak bagi peserta didik dalam rangka melakukan kegiatan-kegiatan yang positif, inovatif dan produktif yang akan membantu peserta didik dalam menumbuhkan karakter. Peran pramuka SDIT Al-Utsmaniyah dalam menumbuhkan karakter kemudian dijabarkan dalam visi dan misi yang telah dibuat dan disepakati bersama antara pembina, guru, serta orang tua dan telah disampaikan kepada peserta didik. Adapun visi dan misi pramuka SDIT Al-Utsmaniyah adalah:

Visi:

- Mewujudkan jiwa pramuka yang tangguh, unggul, berprestasi dan berbudi pekerti luhur berdasarkan iman islam yang kuat.

Misi:

- Menjunjung tinggi nilai-nilai islam yang terkandung dalam kitab suci Al-qur'an.

- Mengembangkan nilai-nilai trisatya dan dasadharma.

- Memperkokoh sikap disiplin dan patuh disetiap anggota pramuka.

- Menjaga ukhuwah Islamiyah sesama anggota, kakak dewan penggalangdan kepada kakak Pembina.

- Rutin mengikuti semua kegiatan pramuka.

- Melatih keberanian mental dan pikiran dalam diri masing-masing anggota.

- Mengembangkan jiwa pramuka yang mandiri, jujur, dan bertanggung jawab.

\section{b. Futsal}

Futsal saat ini menjadi salah satu olahraga populer dan paling banyak diminati. Olahraga ini merupakan turunan dari sepak bola tapi dengan jumlah pemain yang lebih sedikit. Futsal kemudian banyak dijadikan kegiatan ekstrakurikuler di sekolah termasuk di SDIT Al-Utsmaniyah.

Tujuan diadakannya esktrakurikuler futsal di SDIT Al-Utsmaniyah yaitu sebagai salah satu wadah untuk mengembangkan hobi dan menumbuhkan nilai-nilai karakter pada peserta didik. Visi dari ektrakurikuler futsal adalah sebagai pelopor pendidikan sepak bola yang fair play dalam bermain sepak bola, sedangkan untuk menunjang visi tersebut kemudian dikembangkan misi yaitu membentuk pemain yang disiplin, kreatif, dan mampu menahan emosi dalam bertanding serta mampu menjadi pemain yang mampu disegani oleh lawan. Dari penjabaran visi dan misi tersebut maka dapat dikatakan bahwa karakter yang ditumbuhkan melalui kegiatan futsal ini di antaranya adalah sportif, disiplin, kreatif, mandiri, toleransi, dan kerja keras.

\section{c. Pencak Silat}

Pencak silat merupakan budaya Indonesia yang harus dilestarikan. Unsur yang terkandung di dalam pencak silat diantaranya olahraga, seni, dan bela diri. SDIT Al-Ustmaniyah memiliki ekstrakurikuler pencak silat yang merupakan salah satu esktrakurikuler pilihan bagi peserta didik. Visi dan misi dari ekstrakurikuler pencak silat ini adalah "mengembangkan budaya asli Indonesia dan menumbuhkembangkan bakat dan prestasi siswa dibidang pencak silat". Nilainilai karakter akan tumbuh seiring berkembangnya bakat dan potensi yang dimiliki peserta didik serta proses sosialisasi dalam kegiatan ekstrakurikuler.

\section{d. Marawis}

Marawis merupakan salah satu ekstrakurikuler pilihan di SDIT AlUtsmaniyah. Kegiatan marawis melatih peserta didik untuk dapat memainkan alat 
musik marawis (hajir, sambal, dumbuk pinggang, dumbuk batu, dan kepak marawis) serta menyanyikan lagu-lagu islami. Pembina ekstrakurikuler melatih peserta didik secara bergantian agar semua dapat memainkan alat musik dengan baik dan benar serta dapat bernyanyi lagu islami dengan indah.

Marawis selalu menjadi pertunjukkan yang dinantikan saat pentas seni maupun saat perayaan besar umat islam seperti rajaban dan maulid nabi. Peserta didik dari ektrakurikuler marawis dilatih untuk berani tampil di depan umum. Tujuan Kegiatan marawis SDIT Al-Utsmaniyah selain untuk mengembangkan minat peserta didik juga untuk menumbuhkan nilai-nilai karakter. Hal ini dibuktikan dengan dirancangnya visi dan misi untuk menunjang penumbuhan nilai-nilai karakter dalam kegiatan esktrakurikuler marawis. Visi dan misi tersebut di antaranya adalah:

Misi

- Mengembangkan bakat dan prestasi siswa dalam seni musik islami dan melatih mental serta karakter siswa.

Visi

- Melatih pukulan dasar seni marawis.

- Menghadirkan seni islam khususnya marawis dalam ajang pendidikan yang berkarakter.

e. Kaligrafi

Kaligrafi merupakan salah satu karya seni yang menekankan keindahan pada huruf arab. Kaligrafi menuntut sebuah estetika pada pembuatnya. Seni menulis kaligrafi biasanya diajarkan di sekolahsekolah islam. SDIT Al-Utsmaniyah sebagai salah satu sekolah islam menjadikan kaligrafi sebagai ektrakurikuler yang bertujuan mengembangkan bakat dan potensi peserta didik dalam mengenal dan melatih penulisan kaligrafi. Misi dari kegiatan ektrakurikuler kaligrafi ini adalah mempelajari karya seni kaligrafi dan memperoleh karya kaligrafi yang indah.

Kaligrafi sebagai kegiatan ekstrakurikuler dapat dijadikan wadah penumbuhan nilai-nilai karakter seperti karakter religius, kreatif, disiplin, kerja keras, dan mandiri. Tujuan dari penumbuhan nilai-nilai karakter pada peserta didik secara tidak langsung dapat dikembangkan melalui kegiatan yang ada dalam ektrakurikuler kaligrafi. SDIT AlUtsmaniyah mengadakan lomba membuat kaligrafi antar peserta ektrakurikuler bahkan antar kelas. Lomba tersebut diadakan untuk memberikan semangat kepada peserta didik dalam membuat karya seni kaligrafi dan terus mengembangkan karya seni tersebut.

\section{f. Dokter Cilik}

Dokter kecil merupakan ekstrakurikuler yang ada di SDIT Al-Utsmaniyah. Ekstrakurikuler ini memiliki visi yaitu sehat bersama dokter kecil dan memiliki misi yakni "membantu siswa dan masyarakat sekitar agar lebih sehat dan ceria".

Peserta didik dalam kegiatan ekstrakurikuler dokcil diajarkan untuk dapat memberikan pertolongan pertama pada luka ringan. Dokter kecil juga memiliki peran sebagai petugas kesehatan kelas dengan tugas memberikan pertololongan pada teman yang luka ringan. Selain itu Pembina mengenalkan berbagai manfaat dari tanaman disekitar sekolah agar mereka mengetahui bahwa setiap tanaman memiliki manfaat dan mereka bias merawatnya dengan baik.

Pembina melibatkan dokter kecil untuk membantu kegiatan imunisasi yang diadakan oleh puskesmas setempat. Imunisasi diberikan untuk peserta kelas satu sampai kelas tiga, dengan adanya 
bantuan dokcil petugas tidak terlalu kerepotan mengatur peserta didik kelas rendah tersebut. Kegiatan dokter kecil merupakan salah satu bentuk kegiatan yang dapat menumbuhkan nilai-nilai karakter seperti toleransi, mandiri, peduli, dan tanggung jawab.

\section{g. Sains Club}

Sains Club merupakan ektrakurikuler yang banyak menghantarkan SDIT ALUtsmaniyah meraih prestasi dan dikenal oleh masyarakat luas. Latar balakang dibentuk ektrakurikuler sains club yaitu karena setiap tahunnya ada olimpiade sains atau lomba sejenisnya yang mengundang sekolah dasar untuk menjadi peserta.

Tujuan dari ektrakurikuler sains club adalah mempersiapkan peserta didik yang kompeten dalam mata pelajaran khususnya IPA serta menumbuhkan kesiapan mental dan emosional peserta didik dalam menghadapi lomba. Ekstrakurikuler sains club dikhususkan untuk peserta didik kelas 4, 5, dan 6. Pembina akan membentuk peserta didik ke dalam tim-tim kecil serta melatih tim kecil tersebut agar siap mengikuti lomba.

Ekstrakurikuler sains club telah menjuarai lomba yang diadakan oleh KALBE dan sebagai hadiah pembina serta peserta diajak pergi liburan ke Jepang. Dari sini kemudian peserta didik yang lain terpacu untuk terus mengembangkan ilmu sains dan mengikuti berbagai lomba. Dari uraian tersebut terlihat bahwa sains club bukan hanya sebagai wadah menyalurkan bakat akan tetapi sebagai wadah menumbuhkan nilai-nilai karakter pada peserta didik.

Berdasarkan uraian program intrakurikuler maupun ekstrakurikuler SDIT AL-Utsmaniyah di atas maka dapat diketahui bahwa sasaran dalam program sekolah adalah seluruh stakeholder sekolah seperti yayasan, komite, tenaga pendidik dan kependidikan, orang tua serta masyarakat. Adapun tujuan dari program pendidikan karakter yang dirancang dalam berbagai bentuk kegiatan di SDIT AlUtsmaniyah pada dasarnya adalah untuk menumbuhkan nilai-nilai karakter pada diri peserta didik SDIT Al-Utsmaniyah.

\section{Penerapan Pendidikan Karakter}

Pendidikan karakter merupakan pondasi utama dalam menumbuhkan dan membina karakter peserta didik. Proses pendidikan sudah sepatutnya menanamkan karakter di dalam setiap kegiatannya, jika pendidikan hanya menerapkan ilmu pengetahuan saja maka manusia dapat diibaratkan seperti pohon yang terlihat kokoh hanya dari luar saja akan tetapi rapuh akibat dari akar yang tidak kuat menopang. Penerapan pendidikan karakter di setiap lembaga pendidikan akan berbeda satu sama lain tapi sangat jelas bahwa tujuannya yaitu menumbuhkan nilai-nilai karakter pada peserta didik sebagai calon penerus bangsa.

SDIT Al-Utsmaniyah merupakan sekolah yang menerapkan pendidikan karakter di setiap proses kegiatan intrakurikuler maupun ekstrakurikuler sekolah. Hasil penelitian menunjukkan bahwa penerapan pendidikan karakter di SDIT Al- Utsmaniyah diimplementasikan dengan berbagai model di antaranya adalah sebagai berikut.

\section{Pembiasaan}

Manusia pada dasarnya adalah makhluk yang taat, sejak dalam kandungan manusia diperkenalkan dengan sebuah proses kehidupan. Proses bukanlah hal yang tabu bagi manusia, sebuah proses juga yang menuntun manusia menemukan karakternya. Seiring dengan berjalannya waktu banyak proses yang sudah dilalui dan banyak pula hal yang mempengaruhi sehingga menjadikan manusia memiliki 
berbagai karakter. Karakter hakikatnya bersifat dinamis, karakter merupakan sebuah perwujudan dari jalinan yang berkesinambungan dan dilakukan secara terus menerus sehingga menjadi kebiasaan.

Pembiasaan merupakan proses yang dilakukan secara terus-menerus dalam kurun waktu tertentu. Jika nilai-nilai karakter sudah dijadikan sebuah pembiasaan maka lambat laun akan mengkristal di sanubari. Sekolah sebagai lembaga pendidikan sudah sangat dekat dengan sebuah pembiasaan maka dianggap perlu bahwa nilai-nilai karakter dapat lebih didekatkan dengan peserta didik melalui proses dalam kegiatan. Sejak awal masuk sekolah peserta didik SDIT Al- Utsmaniyah sudah mulai diperkenalkan dengan tata tertib dan kebiasan-kebiasaan islami karena ada pepatah yang mengatakan tak kenal maka tak sayang, jadi setelah kenal maka secara perlahan peserta didik akan sayang atau dalam kata lain akan mulai terbiasa.

Pembiasaan yang diterapkan di SDIT AlUtsmaniyah adalah sebagai berikut.

a. Kegiatan berdoa sebelum belajar

Kegiatan berdo'a sebelum memulai proses pembelajaran menjadi sebuah pembiasaan yang sudah tertanam dalam diri peserta didik dan guru SDIT AlUtsmaniyah. Pendidik atau guru menekankan bahwa tujuan berdo'a adalah untuk mempermudah peserta didik menerima dan menyerap pelajaran yang disampaikan serta mempermudah segala kegiatan yang akan dijalani.

b. Pembiasaan makan dan minum sambil duduk.

Pembiasaan makan dan minum sambil duduk sudah mulai dilakukan oleh peserta didik dengan kesadaran sendiri tanpa harus diawasi atau diminta oleh guru. Meskipun tidak dapat dipungkiri bahwa ada beberapa peserta didik yang belum terbiasa atau lupa dengan hal tersebut. Sekolah menerapkan punishment kepada peserta didik yang melanggar aturan makan dan minum sambil duduk. Jika ada peserta didik yang terlihat makan dan minum sambil berdiri maka dikenakan hukuman bending berkelipatan. Maksud bending berkelipatan adalah jika satu kali melanggar maka bending 5 kali sedangkan jika mengulang kesalahan maka bending ditambahkan menjadi dua kali lipat begitu seterusnya dalam satu hari. Hukuman tersebut menimbulkan efek jera pada diri peserta didik terbukti semakin hari peserta didik sudah mulai sepenuhnya sadar terhadap pembiasaan tersebut.

c. Salat dzuhur dan ashar berjamaah

Salat 5 waktu merupakan kewajiban bagi umat muslim, pahala salat berjamaah lebih besar 27x lipat dibandingkan dengan salat munfarid (sendiri). Islam juga menganjurkan untuk melakukan amalan- amalan sunah seperti salat dhuha, salat qobliah ba'diah, dan salat jum'at. Sistem fullday school yang diterapkan sekolah menuntut guru mengembangkan kebijakan terkait salat dhuha dan salat dzuhur serta salat jum'at di sekolah. Jadwal dirancang oleh kepala sekolah bersama- sama dengan guru dan peserta didik, yang kemudian diinformasikan kepada orang tua peserta didik.

d. Membuang sampah pada tempatnya

Membuang sampah pada tempatnya perlu menjadi sebuah pembiasaan, karena banyak bencana di dunia khususnya Indonesia terjadi akibat kelalaian manusia yang sering membuang sampah tidak pada tempatnya. Belakangan ini banjir dan 
longsor sudah menjadi fenomena yang sering terjadi dan faktanya hal tersebut terjadi akibat banyaknya sampah. Salah satu upaya untuk mengatasi masalah sampah yaitu dengan membiasakan diri untuk membuang sampah di tempat yang sudah disediakan.

Pembiasaan yang dilakukan di SDIT AlUtsmaniyah berdampak positif terhadap perubahan karakter peserta didik. Terlihat bahwa nilai- nilai karakter mulai tumbuh dalam diri peserta didik. Nilai- nilai karakter yang terbentuk dari proses pembiasaan diantaranya cinta Allah, tanggung jawab, disiplin dan mandiri, hormat dan santun, peduli dan kerjasama, serta toleran dan cinta damai. Hal tersebut terlihat dari kegiatan keseharian peserta didik.

\section{Keteladanan}

Meskipun jaman sudah modern dan alat komunikasi sudah sangat canggih akan tetapi peran pendidik dalam proses internalisasi nilai-nilai karakter tidak dapat tergantikan begitu saja. Pendidik merupakan contoh ideal terutama dalam pandangan peserta didik, sehingga tingkah laku dan penampilan pendidik secara sadar atau tidak akan ditiru oleh peserta didik.

Keteladanan dalam pendidikan merupakan bagian dari sejumlah metode yang dianggap efektif dalam membentuk karakter peserta didik. Keteladanan menjadi efektif karena pada dasarnya setiap diri manusia memiliki rasa untuk meniru atau mengikuti orang lain. Pendidik sebagai figur yang digugu dan ditiru memiliki tanggung jawab yang sangat besar untuk menanamkan nilai-nilai karakter, karena tugas pendidik bukan hanya mentransfer ilmu pengetahuan. Tanggung jawab tersebut harus dapat dilaksanakan semaksimal mungkin, oleh karena itu pendidik harus memiliki kepribadian yang baik agar dapat menjadi teladan bagi peserta didik. Proses pendidikan karakter yang berkaitan dengan keteladanan di SDIT Al-Utsmaniyah tercakup dalam keteladan berbuat, berucap, berpakaian, bersikap serta keteladanan bersosialisasi. Guru bukan satu- satunya teladan bagi peserta didik akan tetapi seluruh civitas sekolah berperan sebagai teladan bagi peserta didik.

\section{Pembinaan}

Karakter peserta didik berkembang sesuai dengan pengalaman hidupnya. Peserta didik memiliki pemahaman dan daya tangkap yang berbeda, sehingga ada peserta didik yang dengan mudah menerima dan ada pula yang harus dipaksa untuk menerima. Paksaan tersebut biasanya dikembangkan di dalam sebuah peraturan yang kemudian berkembang pula sanksi dan penghargaan di dalamnya. Sanksi harus bersifat membangun bukan malah menjatuhkan mental peserta didik, begitu pula dengan penghargaan harus membuat peserta didik semakin termotivasi bukan malah tinggi hati.

Contoh pembinaan yang ada di SDIT AlUtsmaniyah adalah penerapan sanksi bagi peserta didik yang tidak mentaati tata tertib seperti terlambat datang ke sekolah, 2 minggu berturut-turut tidak melaksanakan salat wajib maupun dhuha, nilai pelajaran menurun, serta membuat kegaduhan di kelas maupun sekolah. Sedangkan penghargaan biasanya dilakukan oleh setiap wali kelas serta setiap kelas memiliki cara pemberian penghargaan yang berbeda.

Prosedur pemberian sanksi di SDIT AlUtsmaniyah yaitu ketika terjadi masalah maka wali kelas yang terlebih dahulu akan menanganinya, kemudian jika masalah tersebut sulit ditangani oleh wali kelas maka wali kelas akan memanggil pihak ketiga yakni wakil kepala sekolah bidang kesiswaan. Masalah yang dianggap sulit dipecahkan walaupun dengan pihak ketiga 
maka sekolah akan memanggil orang tua sebagai langkah akhir pemecahan masalah.

Oleh karena itu, pada saat rapat awal penerimaan peserta didik pihak sekolah selalu memberikan informasi hal-hal terkait kebijakan sekolah supaya nantinya orang tua tidak kaget dan dapat menerima kebijakan yang sudah didiskusikan dari awal selain itu juga supaya orang tua dapat membantu memberikan pemahaman kepada peserta didik.

4. Pembelajaran berbasis CTL

Contextual Teaching and Learning merupakan sebuah konsep belajar yang mendorong guru untuk menghubungkan antara materi yang diajarkan dan situasi nyata peserta didik. CTL dapat dikembangkan menjadi salah satu model pembelajaran berkarakter, karena dalam pelaksanaannya lebih menekankan pada keterkaitan antara materi pembelajaran dengan dunia kehidupan peserta didik secara nyata, sehingga para peserta didik mampu menghubungkan dan menerapkan kompetensi hasil belajar dalam kehidupan sehari-hari. Guru berperan penting membuat proses pembelajaran menjadi menarik karena yang mengetahui situasi peserta didik di kelas yaitu guru. Proses pembelajaran dir SDIT Al- Utsmaniyah di cover secara kreatif oleh guru selain itu di setiap mata pelajaran dan materi pembelajaran selalu menanamkan nilai-nilai karakter. Karakter yang diharapkan dari proses pembelajaran tidak hanya tertuang dalam RPP akan tetapi dalam bentuk nyata pembelajaran.

\section{Peran Guru dan Orang Tua}

Penerapan pendidikan karakter akan maksimal hasilnya jika stakeholder sekolah melaksanakan dengan komitmen yang tinggi. Ujung tombak pelaksanaan pendidikan adalah guru. Guru adalah pendidik profesional dengan tugas utama mendidik, mengajar, membimbing, mengarahkan, melatih, menilai, dan mengevaluasi peserta didik. Guru sebagai sosok yang digugu dan ditiru, mempunyai peranan penting dalam implementasi program pendidikan karakter. Nilai-nilai karakter sudah sepatutnya diterapkan dalam setiap kegiatan sekolah baik kegiatan kelas maupun di luar kelas.

Peran guru selain sebagai implementasi program juga berperan sebagai fasilitator dan motivator. Program yang dijalankan pasti akan membutuhkan fasilitas, oleh sebab itu guru harus senantiasa memfasilitasi kebutuhan peserta didik terkait program yang akan dijalankan. Fasilitas yang memadai akan menunjang kelancaran dan keberhasilan kegiatan, sehingga program berjalan efektif dan efisien. Secara naluri peserta didik pasti akan merasakan kejenuhan terhadap rutinitas yang dilaksanakan, dalam keadaan seperti ini maka guru harus senantiasa membangkitkan motivasi peserta didik. Motivasi eksternal memang bersifat sementara akan tetapi biasanya peserta didik akan merasa terkesan jika guru memberikan perhatian.

Implementasi program pendidikan karakter di SDIT Al-Utsmaniyah tidak terlepas dari peran guru sebagai pelaksana kegiatan di kelas maupun luar kelas. Guru SDIT Al-Utsmaniyah mengimplementasikan program pendidikan karakter dengan mengintegrasikannya melalui mata pelajaran dan kegiatan intrakurikuler maupun ekstrakurikuler sekolah. Keaktifan dan kekreatifan guru merupakan faktor penentu ketercapaian program di SDIT AlUtsmaniyah.

SDIT Al-Utsmaniyah senantiasa memfasilitasi setiap program yang diterapkan di sekolah, guru diberikan 
tanggung jawab untuk mengelola fasilitas yang sudah tersedia. Sekolah berharap bahwa fasilitas tersebut akan lebih tepat penggunaannya jika dikelola oleh guru, karena guru yang lebih mengetahui apa yang dibutuhkan oleh peserta didik. Fasilitas yang disediakan sekolah untuk menunjang program pendidikan karakter di antaranya masjid, ruang multimedia, lapangan olahraga, dan laboratorium alam. Pada saat peserta didik mulai bosan dengan kegiatan belajar, guru memotivasi dengan cara memberikan ice breaking, games, dan mengajak peserta didik belajar di alam (outing class).

Peran orang tua merupakan faktor pendukung dalam menumbuhkan karakter peserta didik, karena pendidikan utama terbentuk dari keluarga. Peserta didik lebih banyak menghabiskan waktu di rumah dibandingkan di sekolah, sehingga orang tua harus berperan aktif dalam membimbing setiap kegiatan peserta didik di rumah. Adapun peran orang tua SDIT AlUtsmaniyah di antaranya sebagai fasilitator yaitu memberikan fasilitas untuk memudahkan proses belajar peserta didik, dan sebagai motivator artinya orang tua berperan untuk meningkatkan semangat belajar peserta didik, serta pendukung implementasi program sekolah agar tujuan sekolah dapat terlaksana dengan baik.

SDIT Al-Utsmaniyah bekerjasama dengan orang tua untuk mengimplementasikan program pendidikan karakter melalui pengisian buku penghubung, kajian rutin 1 bulan sekali, dan rapat tahunan. Selain sebagai pendukung implementasi program, orang tua juga senantiasa bekerjasama dengan sekolah untuk memfasilitasi kebutuhan peserta didik, seperti pada saat akan diadakan praktek, pentas seni, study tour, dan outing class. Fasilitas yang diberikan oleh orang tua berupa materi maupun non materi. Fasilitas sekolah yang memadai akan mendukung terbentuknya motivasi belajar peserta didik, motivasi bukan hanya terkait fasilitas melainkan bisa terbentuk dari guru maupun orang tua. Motivasi yang diberikan oleh guru tidak akan cukup jika tidak diiringi motivasi dari orang tua. Guru dan orang tua di SDIT AlUtsmaniyah saling bekerjasama memotivasi peserta didik dengan cara berkomunikasi baik secara langsung maupun melalui media sosial, hal ini bertujuan untuk bertukar pikiran mengenai perkembangan dan motivasi peserta didik.

\section{KESIMPULAN DAN IMPLIKASI}

\section{Kesimpulan}

Berdasarkan hasil hasil penelitian, maka dapat disimpulkan beberapa hal yakni:

1. program pendidikan karakter SDIT AlUtsmaniyah diimplementasikan melalui program intrakurikuler dan ektrakurikuler;

2. guru dan orang tua memiliki peranan dalam proses penerapan pendidikan karakter di SDIT Al-Utsmaniyah.

\section{Implikasi}

Berdasarkan hasil penelitian yang telah diperoleh, implikasi dari penelitian ini adalah:

1. bagi Sekolah Dasar negeri dan swasta, diharapkan dapat menerapkan pendidikan karakter dalam program sekolah;

2. guru senantiasa menjadi teladan bagi peserta didik dalam hal penumbuhan nilai-nilai karakter dan selalu menjalin silaturahmi yang baik dengan orang tua agar setiap program dapat berjalan sesuai dengan tujuan yang akan dicapai. 


\section{DAFTAR PUSTAKA}

Gunawan H. 2012. Pendidikan karakter:

Mulyasa E. 2013. Manajemen pendidikan konsep dan implementasi. Alfabeta, Bandung.

Indonesia Corruption Watch. 2015. Bulletin Mingguan Anti-Korupsi: 14-18

Iskandar. 2013. Metodologi penelitian pendidikan dan sosial. Referensi, Jakarta. karakter. Bumi Aksara, Jakarta.

Muslich M. 2011. Pendidikan karakter: menjawab tantangan krisis multidimensional. Bumi Aksara, Jakarta.

Samami M dan Hariyanto. 2011. Pendidikan karakter. Remaja Rosdakarya, Bandung. 